\title{
Paisatge, clima, perill, por i patiment: una ullada al Mediterrani occidental a l'època moderna*
}

\author{
Armando Alberola Romá \\ Grup de Recerca en Història i Clima \\ Universitat d'Alacant
}

A M. Àngels Pérez Samper, amb afecte
i reconeixement, en el seu curs jubilar.

\section{Resum}

El Mediterrani, mar entre mars, és un personatge històric singular. Aquesta anàlisi pretén destacar les seues característiques polièdriques i la singularitat dels seus molts paisatges, encara que fent major atenció als que han pogut passar més desapercebuts durant els segles moderns. És evident que el clima ha condicionat els paisatges, les formes de vida quotidiana o les diferents activitats econòmiques, com ara el conreu de la terra, la navegació comercial i de guerra, l'explotació de la sal o la comercialització de la neu i el gel. També els fenòmens extrems de la naturalesa han impactat en les terres i en les gents mediterrànies, amb les seues implicacions politicoeconòmiques, religioses o mentals. En última instància, els problemes biològics i sanitaris, especialment els derivats de l'acció de les febres, van condicionar igualment el desenvolupament econòmic i social de tots els que habitaren en la conca occidental del Mediterrani.

* Aquesta contribució forma part dels resultats del projecte de recerca HAR2or7-828Io-P, inclòs en el Programa Estatal de Foment de la Recerca Científica i Tècnica d'Excellència promogut pel Ministeri de Ciència, Innovació i Universitats del Govern d'Espanya. En línies generals, respon a la ponència pronunciada el i8 de desembre de 2018 en la sessió «Paisatge històric i risc natural» del VIII Congrés d'Història Moderna de Catalunya, celebrat a la Universitat de Barcelona els dies 17-20 de desembre de 2018 . 
Paraules clau: mar Mediterrani, segles XVI-XVIII, clima, paisatge, risc i perill, por, febres.

Paisaje, clima, peligro, miedo y sufrimiento: un vistazo al Mediterráneo occidental en la época moderna

\title{
Resumen
}

El Mediterráneo, mar entre mares, es un personaje histórico singular. Este análisis pretende destacar las características poliédricas de su cuenca y la singularidad de su variada geografía, pero prestando atención a aquellos aspectos que han podido pasar más desapercibidos durante los siglos modernos. Es evidente que el clima ha condicionado los paisajes, las formas de vida cotidiana y las diferentes actividades económicas, como, por ejemplo, el cultivo de la tierra, la navegación comercial y bélica, la explotación de la sal o la comercialización de la nieve y el hielo. Asimismo, los fenómenos extremos de la naturaleza han impactado en las tierras y las gentes mediterráneas, con sus implicaciones político-económicas, religiosas o culturales. Por último, también los problemas biológicos y sanitarios, sobre todo los derivados de la acción de las fiebres, han condicionado el desarrollo económico y social de todos cuantos han habitado en la cuenca occidental del Mediterráneo.

Palabras clave: mar Mediterráneo, siglos XVI-XVIII, clima, paisaje, riesgo y peligro, miedo, fiebres.

\section{Landscape, climate, danger, fear and suffering: a look at the western Mediter- ranean in the modern era}

\begin{abstract}
The Mediterranean, a sea between seas, is a singular historical character. This analysis aims to highlight its polyhedral characteristics and the uniqueness of its many landscapes, with an emphasis on those that went somewhat unnoticed during the modern era. Evidently the climate has conditioned these landscapes, as well as different ways of life and various economic activities, such as agriculture, commercial and naval shipping, and the commercial exploitation of salt, snow and ice reserves. Natural phenomena have also influenced the lands and people of the Mediterranean, with their corresponding politico-economic, religious and mental implications. Lastly, biological and
\end{abstract}


health issues, especially those resulting from the actions of fevers and diseases, affected the economic and social development of those who lived in the western Mediterranean basin.

Keywords: Mediterranean sea, $16^{\text {th }}-18^{\text {th }}$ centuries, climate, landscape, risk and danger, fear, fevers.

\section{Introducció}

Des dels anys huitanta del segle passat sostinc una especial relació amb aquest "personatge històric» que és el Mediterrani, del qual Fernand Braudel, un dels seus grans historiadors, va destacar el caràcter dual que atresorava. ${ }^{I}$ D'una banda, hi ha un Mediterrani "terrestre i aquàtic», on trobem la realitat física, econòmica, social i cultural del vell Mare Interum o Mare Nostrum; un espai on la gent va aprendre a fer front als problemes derivats de viure en un medi complex i multipaisatgístic. Convivint amb aquest, tenim un altre Mediterrani, de caràcter «aeri», dotat d'una dinàmica atmosfèrica particular que planeja, influeix i condiciona l'altre.

L'anàlisi "global» braudelià s'enfonsa ja en la nit dels temps de la historiografia modernista, però encara manté el seu vigor i la seva influència. ${ }^{2}$ Estudis més recents, com els de David Abulafia, ${ }^{3}$ àdhuc considerant que constitueixen l'essència del Mediterrani «la superfície del mateix mar, les seues costes, les seues illes i especialment les seues ciutats portuàries», aposta per historiar les seues gents, els "pobles que van

I. Fernand Braudel, El Mediterráneo y el mundo mediterráneo en la época de Felipe II, Madrid, Fondo de Cultura Económica, 1976, 2 vols. Armando Alberola RomÁ, «La lucha del hombre contra el medio en el Mediterráneo occidental y su incidencia en las tierras valencianas durante la Edad Moderna», Canelobre, I2/13 (primavera/estiu I988), pp. 45-54.

2. Fernand Braudel va defensar la seua tesi doctoral en 1947 , la qual va ser publicada per l'editorial parisenca Armand Colin en 1949.

3. D. Abulafia, ed., El Mediterráneo en la historia, Crítica-Thames \& Hudson Ltd., Londres, 2003; D. ABulafia, El gran mar: una historia humana del Mediterráneo, Crítica, Barcelona, 2016. 
creuar el mar i que van viure [...] en els seus ports i illes». ${ }^{4}$ I, a més, ho fa en el llarguíssim interval que s'estén des de l'any I.200 abans de Crist fins a la segona meitat del segle xx. Però, en gran manera, Abulafia pren en compte plantejaments braudelians relatius, per exemple, a la importància i l'impacte del règim dels vents i corrents, així com a les condicions meteorològiques; és a dir, tot el que afecta tant el Mediterrani «líquid» i els seus intercanvis comercials, com el "terrestre», on el conreu de la terra, la lluita contra el medi i l'obtenció de rendiments agrícoles suficients resulten fonamentals per al funcionament correcte de les activitats quotidianes. 5

Estem, doncs, enfront d'un espai geogràfic; però també davant — com deia Braudel — d'un "personatge històric» i, per tant, d'una estructura sobre la qual descansa una història comuna, com indica la professora Pérez Samper en el pròleg d'un llibre recent. ${ }^{6}$ Ja m'agradaria endinsar-me en tots els detalls que aquest complex "personatge» ofereix, però, malauradament, no és possible per qüestions d'espai. Em limitaré, en conseqüència, a reflexionar sobre certs aspectes que em semblen rellevants i que, per descomptat, m'interessen en gran manera.

\section{Paisatge i clima}

Més que a un paisatge, hauríem de referir-nos a "paisatges», a nombrosíssims paisatges sobre els quals es van assentar civilitzacions successives que van interactuar entre si i que van dotar el Mare Nostrum, i tots els «mars enmig de terres» que inclou, d'aqueix caràcter integrador que ha durat mil.lennis i que ha configurat una forma de vida vinculada al medi però també a influències culturals, econòmiques i polítiques de tot tipus. Deia Braudel:

4. Abulafia, El gran mar, pp. 7-II.

5. Ibidem, pp. 20-23.

6. M. Á. Pérez Samper, coord., La Mediterrània a l'època moderna. Societat, poder i cultura, Arpegio, Barcelona, 20I8. Vegeu, així mateix, Pedralbes. Revista d'Història Moderna, 38 (20I8), Mon maritim mediterrani a l'època moderna (núm. monogràfic). 
[...] el Mediterrani és [...] un complex de mars, i de mars, a més, esguitats d'illes, tallats per penínsules, envoltats de costes ramificades. [...] és el mar de les oliveres i els vinyers, tant com el dels estrets vaixells de rems o els navilis redons dels mercaders, i la seua història no es pot separar del món terrestre que ho embolica. ${ }^{7}$

El Mediterrani, a banda de cruilla cultural i socioeconòmica, ha estat i és un àmbit ple de contrastos determinats pels condicionants físics i climàtics que li són propis i que, per descomptat, van afectar i afecten els éssers humans que els van habitar i els habiten. Per tant, no és únicament un paisatge de vinyers i olivars, d'hortes o de secans coberts de cereal, de planícies suaus que s'estenen fins a abraçar un mar tebi obert a totes les destinacions. Aquest «mar de mars» és també un paisatge aspre i muntanyenc —o «adust i marginal», en paraules de Braudel - on, en el seu interior i a pocs quilòmetres de la costa, es poden trobar becs amb altures que superen els 4.000 metres sobre el nivell del mar i que fan que el clima càlid costaner s'endurisca i es torni rigorós i destemprat.

En terres valencianes i catalanes hi ha muntanyes que superen, respectivament, els I.800 i 3.I00 metres d'altura, que a la serralada Penibètica s'eleven a quasi 3.500 en el bec del Mulhacén, però que al Marroc o a la península Itàlica poden tindre, encara, més altitud. Pel que fa a les primeres i després de trepitjar-les a les acaballes del segle XVIII en un viatge d'estudi encarregat per Carles IV al botànic il.lustrat Antoni Josep Cavanilles i que va donar com a resultat les seues magnífiques Observaciones, ${ }^{8}$ el científic manifestava l'abundància de muntanyes de llarg a llarg del territori que "dificultan el paso" i precisava que de les «838 leguas cuadradas de 20 al grado» que integraven «la superfície entera del antiguo reyno de Valencia [...][,] las 240 con

7. Braudel, El Mediterráneo, I, p. I3.

8. Antonio José Cavanilles, Observaciones sobre la historia natural, geografía, agricultura, población y frutos del reyno de Valencia, Imprenta Real, Madrid, I795-I797, 2 vols. 
corta diferencia son llanuras o valles, las restantes son montes».9 Quasi dos segles abans, el cronista Gaspar Escolano es manifestava de manera molt semblant. ${ }^{\text {Io }}$

A Catalunya trobem un país igualment montuós, amb tres grans estructures geològiques perfectament definides: les serralades costaneres, la depressió Central i els Pirineus; cadascuna d'aquestes, amb les seues especificitats i característiques. Una mena de laberint, però també de paisatge simbòlic, ${ }^{\text {II }}$ de passadís i, fins i tot, de refugi — com va escriure Pierre Vilar-, amb la virtut de tindre un relleu millor articulat que el de les costes valencianes. ${ }^{12}$ En èpoques passades, aquestes orografies difícils, de mala petja i hiverns rigorosos, van propiciar, sobretot als espais interiors, la creació de llocs de llibertat i d'acollida de dissidències — moriscs, bandolers, fugitius de la justícia, entre d'altres—, així com el desenvolupament de fórmules de resistència en un context pròxim a l'autarquia econòmica, ben allunyat de la bonança costanera, on sobreviure no era tasca facil.

Però hi ha més paisatges a banda de l'orogràfic i l'agrari, o dels negocis terrestres i marítims, ben estudiats i coneguts, per cert. Paisatges potser una mica més inaprehensibles, sensitivament menys perceptibles, que cal vincular a circumstàncies de caire físic i geològic, climàtic,

9. Ibidem, vol. I, p. II.

Io. Escolano es referia en les seues Décadas, escrites a començaments del segon decenni del segle XviI, a la complicada orografia valenciana i precisava que, al costat dels elevats cims, es dibuixaven "plans en forma de ferradura o mitges llunes denominats planes» on l'agricultura podia florir si es donaven un mínim de condicions favorables; Gaspar Escolano, Décadas de la Historia de la insigne y coronada ciudad y reino de Valencia, Patricio Mey, València, I6IO-I6II, llibre iv, cap. i, col. 654. Cayetano Mas GalvaÑ, «Natura i catàstrofes en les Décadas de Gaspar Escolano», Afers. Fulls de Recerca i Pensament, 69 (20II), pp. 3II-336.

II. Agustí Alcoberro, «Les primeres geografies de Catalunya (segles XVI-XVIII): els límits del territori, les divisions comarcals i alguns paisatges simbòlics», a J. Dantí, coord., Relacions mediterrànies a la Catalunya moderna, Rafael Dalmau, Barcelona, 20I8, pp. I34-I6I, esp. p. I56 i seg.

I2. Pierre Vilar, Catalunya dins l'Espanya moderna. Recerques sobre els fonaments econòmics de les estructures nacionals, Edicions 62, Barcelona, I, pp. 229-236 i 333-335. 
biològic i sanitari o, fins i tot, emocionals — com el risc o la por-, però que també es troben ben presents de cap a cap de les aigües i les terres mediterrànies durant segles.

\section{I. Sequera i inundació, fred i calor}

Parlar del clima mediterrani és alludir a bon sol, a la llum, a temperatures suaus al llarg de l'any, a la bonança i tranquilllitat, a l'absència de núvols o al gaudi d'una aparent vida plaent a la qual aspiren, amb enveja, els habitants de l'Europa central i septentrional. No obstant això, el clima mediterrani també significa, fonamentalment per al camperol, el patiment d'una pluviometria capriciosa i traïdora que fa que l'excés i la mancança d'aigua $-\mathrm{o}$ siga, tempestes de gran intensitat, riuades $\mathrm{i}$ inundacions barrejades amb sequeres persistents — hagen sigut al llarg de la història les dues cares de la mateixa moneda.

La sequera ha estat sempre - hi ho és a hores d'ara - un enemic funest i terrible que feia malbé les collites any rere any. De la mateixa manera, les precipitacions, habitualment escasses quasi tot l'any, podien oferir — com avui- màxims a la primavera i, sobretot, a la tardor que trencaven els períodes de sequera, provocaven greus inundacions $\mathrm{i}$ terribles estralls en vies de comunicació, en infraestructures hidràuliques i de comunicació i en nuclis urbans, i afectaven, també molt negativament, els conreus pel seu caràcter torrencial.

La sequera i els seus efectes, ben estudiats en l'àmbit mediterrani peninsular ibèric al llarg de la història, han sigut combatuts des de temps immemorial pels camperols i pel comú de viles i ciutats. ${ }^{13} \mathrm{El}$ disseny i l'organització, des de l'època musulmana, de regadius deficitaris però de gran eficàcia i exhaustiu aprofitament hídric per còmput

13. Armando Alberola Romá, «Sécheresses et inondations dans le bassin méditerranéen espagnol aux XVI et XVII siècles. Réflexions au sujet des terres valenciennes», a Armando Alberola Romá, Riesgo, desastre y miedo en la península Ibérica y México durante la Edad Moderna, Publicacions de la Universitat d'Alacant / El Colegio de Michoacán, Alacant / Zamora de Michoacán, 2017, pp. I35-I5O. 
horari, la utilització de petites preses, assuts o boqueres per a retenir $\mathrm{i}$ desviar les aigües d'avinguda cap als camps de cultiu, o la utilització de sènies per a elevar aigües subterrànies, constitueixen testimoniatges reveladors de la secular tenacitat dels mediterranis per a fer front als inconvenients mediambientals. També ho és la construcció, ja durant els segles moderns, d'embassaments de diferent entitat, alguns d'ells modèlics, com el de Tibi (Alacant) a les acaballes del segle XVI, per a regular els complexos cursos fluvials valencians i catalans i recollir els excessos hídrics provinents de les precipitacions extraordinàries equinoccials amb la finalitat de regar els camps en els moments més delicats de l'any agrícola. ${ }^{14}$ Encara es poden contemplar testimoniatges d'aquestes joies hidràuliques, si bé és cert que es troben en molt diferent grau de conservació per la manifesta desídia dels poders públics.

I és que la pluja al Mediterrani, i sobretot a les nostres terres, no sap ploure... I, com encertadament manifesta el cantautor xativí Raimon en una de les seues cançons, si «plou poc és la sequera, si plou massa és el desastre». ${ }^{15} \mathrm{El}$ remei passava per la prevenció, per adoptar mesures semblants a les exposades línies enrere, però, produïda la catàstrofe — bé en forma de sequera persistent, bé com a riuada i inundació violentes—, la celebració de rogacions demanant a l'altíssim el cessament del desastre esdevenia, en el context d'una societat sacralitzada, l'eina considerada més eficaç. No puc entrar en els detalls respecte a aquesta qüestió, però l'estudi de les cerimònies de rogatives pro pluvia permet detectar amb prou precisió els cicles de sequera i la seua gravetat. ${ }^{16}$ Així mateix, les

I4. Armando Alberola Romá, El pantano de Tibi y el sistema de riegos en la Huerta de Alicante, Instituto de Cultura "Juan Gil-Albert» / Fundació CAM, Alacant, 1994. Antonio López Gómez, Els embassaments valencians antics, Generalitat Valenciana, València, 1987.

I5. Armando Alberola Romá, Quan la pluja no sap ploure. Sequeres i riuades al País Valencià en l'Edat Moderna, Publicacions de la Universitat de València, València, 20ıo. La cançó de Raimon és Al meu país la pluja (1983).

i6. Javier MARTÍn Vide i Mariano BarRiEndos, «The use of rogation ceremony records in climatic reconstruction: a case study form Catalonia (Spain)», Climatic Change, 30 (1995), pp. 20I-22I. Tomás Peris Albentosa, «La religiosidad instrumental comunitaria en la Ribera del Júcar durante los siglos Xvi-Xvin: el ejemplo de las 
rogatives pro serenitate evidencien l'abast del desastre hídric, la por de la gent i el desig que tot acabés d'una vegada per sempre. I quan açò succeïa, la celebració de tedèums i de misses d'acció de gràcies era la millor prova que la situació tendia a normalitzar-se. ${ }^{17}$

Però hi ha una qüestió fonamental que no puc deixar a banda en els meus comentaris i reflexions. Els segles moderns van estar dominats per l'oscillació anomenada petita edat del gel, un fenomen d'abast global i de refredament progressiu del clima que es va iniciar al començament del segle XIV, després de l'òptim climàtic medieval, i es va perllongar fins a l'últim terç del segle XIx. En la seua fase més aguda, la petita edat del gel va coincidir amb l'edat moderna i els seus trets essencials van ser la gran variabilitat, irregularitat i extremisme meteorològic, circumstàncies que van provocar l'empitjorament relatiu de les condicions ambientals, el descens de les temperatures mitjanes de la Terra entorn d'I-2 ${ }^{\circ} \mathrm{C}$, l'increment de la freqüència del fred hivernal a l'Europa central i septentrional i un augment substancial de les precipitacions. En aquesta llarga seqüència temporal es van donar diverses fases o oscillacions en les quals l'empitjorament va ser notable; per aquest motiu, més que parlar d'una situació "homogènia» de canvi climàtic, hem de referir-nos a una gran variabilitat en les temperatures i a notables diferències regionals. ${ }^{\mathrm{I}}{ }^{8}$ Van ser nombrosos els hiverns perllongats i molt se-

rogativas», a A. Alberola i J. Olcina, eds., Desastre natural, vida cotidiana y religiosidad popular en la España moderna y contemporánea, Publicacions de la Universitat d'Alacant, Alacant, 2009, pp. 335-390. Armando Alberola Romá, Eduardo Bueno VerGARA i Adrián GARCía TORRES, «Sequía y rogativas en tierras meridionales valencianas durante el siglo xviII", dins L. A. Arrioja i A. Alberola, eds., Clima, desastres y convulsiones sociales en España e Hispanoamérica, siglos XVII-XX, Publicaciones de El Colegio de Michoacán / Publicacions de la Universitat d'Alacant, Zamora de Michoacán / Alacant, 2016, pp. 123-156.

17. Armando Alberola Romá, "Clima, desastre y religiosidad popular en los dietaristas valencianos de los siglos XVI y XvII", Obradorio de Historia Moderna, 25 (20I6), pp. 4I-66.

I8. Hubert H. Lamb, Climate: Present, Past and Future, Methuen and Co. Ltd., Londres, 1972; Hubert H. Lamb, Climate history and the Modern World, Methuen and Co. Ltd., Londres, 1982. Jean M. Grove, The Little Ice Age, Routledge, Londres, 1988. 
vers, seguits de primaveres curtes i humides a les quals van succeir estius que van ser frescos i alguns, fins i tot, calorosos. Per descomptat, les terres de la façana mediterrània de la península Ibèrica van patir hiverns de fred molt intens, estius de calor insuportable, sequeres llargues i episodis de precipitacions d'altíssima intensitat horària que provocaven els desbordaments dels rius, fortes avingudes i inundacions. ${ }^{\text {I9 }}$

Per tant, variabilitat i irregularitat climàtiques, amb significatives diferències regionals, van dominar en aquests segles, en els quals, a més, s'inscriuen fases o pulsacions en què el temps va empitjorar en gran manera. Així, per exemple, el fred va ser intensíssim als anys seixanta del segle XVI, entre I645 i I7I5 i en l'últim terç del segle XVIII i el principi del xIx. La segona d'aquestes pulsacions rep el nom de minim de Maunder i l'extrema gelor d'aleshores va ser conseqüència de l'acusat descens de l'activitat solar. La tercera, coneguda com a oscil.lació Maldà, va afectar sobretot el Mediterrani occidental i la seua singularitat resideix en el fet que, per primera vegada en la història, es van produir simultàniament esdeveniments hidrometeorològics extraordinaris de signe contrari amb efectes catastròfics. ${ }^{20}$

A la façana mediterrània, l'increment de l'activitat tempestuosa es va produir en els períodes I570-I630, I760-I800 i I830-I870. La intensitat va ser similar en el primer i el tercer, amb un augment de la freqüència de les precipitacions catastròfiques i un descens de les sequeres; mentre que en el segon, com ja s'ha indicat, va estar activa l'oscillació Maldà, amb les peculiaritats anotades. Becs de sequera severa es van donar durant els anys I560-I570, I620-I630, I750-I760 i I820-I830,

Armando Alberola Romá, Los cambios climáticos. La Pequeña Edad de Hielo en España, Cátedra, Madrid, 20I4.

19. Armando Alberola Romá, «La Petita Edat del Gel en terres valencianes», dins J. Olcina i E. Moltó, eds., Climes i temps del País Valencià, Publicacions de la Universitat d'Alacant, Alacant, 20I9, pp. 27-37.

20. Mariano Barriendos i Carmen Llasat, «El caso de la anomalía "Maldà" en la cuenca mediterránea occidental (I760-I800). Un ejemplo de fuerte variabilidad climática», dins A. Alberola i J. Olcina, eds., Desastre natural, vida cotidiana y religiosidad popular, pp. 253-286. 
mentre que les sequeres moderades van tenir lloc en els períodes I700I7IO, I760-I770 i I840-I860. ${ }^{21}$

Aquestes circumstàncies negatives van provocar la reiteració de collites dolentes, si no la pèrdua total de la producció, i l'aparició d'una crisi de subsistència, l'increment dels preus del gra i la irrupció de la fam, del malestar social i dels aldarulls. I la cosa encara podia agreujar-se més amb l'arribada de plagues agrícoles i epidèmies — com la pesta o les febres tercianes - o amb el desencadenament de fenòmens naturals amb conseqüències destructives, com és el cas dels terratrèmols i les erupcions volcàniques. ${ }^{22}$ Abundant informació oficial i privada refereix amb precisió totes les circumstàncies esmentades, així com els patiments de la gent de l'època, i dibuixa un panorama de crisi demogràfica, econòmica i social —i no tan sols climàtica- durant els segles XVI-XVIII. ${ }^{23}$

2I. Mariano BARRIENDOS, «Variabilidad climática a escala plurisecular. Reconstrucción a partir de fuentes documentales históricas», dins A. Sousa, L. García-Barrón i V. Jurado, coords., El cambio climático en Andalucía: evolución y consecuencias medioambientales, Consejería de Medio Ambiente (Junta de Andalucía) / Colegio Oficial de Biólogos de Andalucía, Sevilla, 2007, pp. 45-54. Mariano Barriendos i Javier Martín VIDE, «Secular climatic oscillations as indicated by catastrophic floods in the Spain mediterranean coastal area (I4 $4^{\mathrm{TH}}-19^{\mathrm{TH}}$ centuries)», Climatic Change, 38 (I998), pp. 473-49I.

22. Armando Alberola Romá, Catástrofe, economía y acción política en la Valencia del siglo XVIII, Institució Alfons el Magnànim, València, I999; Armando AlberolA RomÁ, «Terremotos, memoria y miedo en la Valencia de la Edad Moderna», Estudis, 38 (20I2), pp. 55-75; del mateix autor "No hay resistencia contra el poder de los elementos enfurecidos: el terratrèmol de Montesa-Estubeny del I748», dins E. Guinot, F. Andrés, J. Cerdá, J. F. Pardo, eds., Santa María de Montesa: la orden militar del reino de Valencia (ss. XIV-XIX), Publicacions de la Universitat de València, València, 20I9, pp. 309-323; Adrián GARCía TORRes, Riesgo climático y desastre en tierras meridionales valencianas durante el siglo XVIII, Publicacions de la Universitat d'Alacant, Alacant, 20I8. Armando Alberola Romá i David Bernabé Gil, «Tercianas y calenturas en tierras meridionales valencianas: una aproximación a la realidad médica y social del siglo xviII», Revista de Historia Moderna. Anales de la Universidad de Alicante, I7 (1998-1999), pp. 95-II2.

23. Armando Alberola Romá i Cayetano Mas Galvañ, «Vulnerabilidad y capacidad de resistencia frente al desastre en la España mediterránea (siglos XVI-XVIII). Fuentes para su estudio", dins L. A. Arrioja i A. Alberola, eds., Clima, desastres y 


\section{Conreant la mar: salines i saliners}

No entraré a comentar les característiques del paisatge agrari, ben estudiat, per cert, des de sempre, ni faré esment de la trilogia típica que es veu a les seues terres. No obstant açò, sí que pararé esment a una activitat amb una gran tradició i enormement rendible en l'àmbit mediterrani durant la modernitat com va ser, i encara ho és avui dia, el «conreu» i la comercialització de la sal.

Des de l'edat mitjana, la producció i distribució de sal en el Mediterrani va constituir una destacada activitat econòmica que donava treball a moltes persones i proporcionava beneficis econòmics importants. ${ }^{24} \mathrm{De}$ consum indispensable per a homes $\mathrm{i}$ animals, com a condiment domèstic, per a conservar carn i peixos, utilitzada en la indústria de l'adob de pells, també en la farmacopea i, fins i tot, com a recobriment interior dels forns de coure pa, no debades la sal fou considerada factor unificador de les economies nord-europea i mediterrània, així com la «cinquena senyora» dintre de les mercaderies principals que circulaven per les rutes comercials de l'interior africà des del segle $\mathrm{xV} .^{25}$

convulsiones sociales en España e Hispanoamérica, siglos XVI-XX, Publicaciones de El Colegio de Michoacán / Publicacions de la Universitat d'Alacant, Zamora de Michoacán / Alacant, 20I6, pp. 4I-60.

24. Michel Mollat, «Le trafic maritime du sel: caractères généraux et position de problèmes", dins M. Mollat, dir., Le rôle du sel dans l'Histoire, P. U. F., París, I968, pp. 307-322. Jean Claude HocQuet, Le sel et la fortune de Venise. (I) Production et monopole. (II) Voilers et commerce en Méditerranée, I200-I650, Presses Universitaires de Lille, Lille, 1978-1979. Miguel Gual Camarena, «Por un mapa de la sal hispana en la edad moderna", dins Homenaje a Jaime Vicens Vives, Universitat de Barcelona, Barcelona, 1965, I, pp. 483-497. Vegeu abundants referències bibliogràfiques a aquesta temàtica en Armando Alberola Romá, «La sal en el Mediterráneo occidental durante la edad moderna. Anotaciones para una reflexión", dins J. Molina Vidal i M. J. Sánchez Fernández, eds., El Mediterráneo: la cultura del mar y de la sal. III Congreso Internacional de Estudios Históricos, Ajuntament de Santa Pola, Santa Pola, 2005, pp. I49-165.

25. Fernand Braudel, Civilización material, economía y capitalismo. Siglos XVXVIII. Las estructuras de lo cotidiano, Alianza, Madrid, I984, I, pp. I7I-I72. BRAUdeL, El Mediterráneo, I, p. 239 i 26I. 
Al Mediterrani hispànic són ben conegudes les principals salines, tant les litorals com les interiors o les localitzades en illes, com és el cas de les d'Eivissa. Aquesta va ser considerada des de temps immemorial com «'illa de la sal» al Mare Nostrum ${ }^{26}$ i la seguien en fama les llacunes meridionals alacantines de la Mata i Torrevella, ja que la sal de la primera superava en qualitat fins i tot l'eivissenca. No obstant això, l'illa pitiüsa va constituir un referent imprescindible de les escales del comerç marítim i a partir del segle xvI va formar part de l'eix Alacant-Balears-Sardenya-Livorno, considerat com el més pròsper del vell Mare Interum. ${ }^{27}$ Les destinacions fonamentals de la sal d'Eivissa en el Mediterrani van ser Venècia, Gènova, el Magreb central, Nàpols, Mallorca i, a partir del segle xvi, Ragusa, Ancona i, fins i tot, Flandes; la relació amb els països del nord d'Europa es va mantenir fins al segle XvII.

La sal de la Mata, ben coneguda des de l'antiguitat, abastia una part important del territori valencià des del magatzem de Vinaròs —on arribava per via marítima des del sud alacantí- i nombrosos pobles d'Aragó. ${ }^{28}$ També protagonitzava una lucrativa exportació a diferents enclavaments mediterranis, com ara Venècia, Ragusa i Gènova, així com Holanda, Anglaterra, Suècia i Dinamarca. L'explotació salinera de la llacuna de Torrevella té una trajectòria ben diferent de la de la Mata i, després de diferents intents i assaigs al llarg dels segles, la seua explo-

26. Juan Vilá Valentí, «Ibiza y Formentera, islas de la sal», Estudios Geográficos, vol. I4, 52 (1953), pp. 363-408. Jean Claude HocQueT, «Ibiza, encrucijada del comercio marítimo y testigo de una coyuntura mediterránea (I250-I650 aprox.)", dins Comercio marítimo en el Mediterráneo medieval y moderno, Universitat de Granada, Granada, 2002, pp. 26-30. Armando Alberola Romá, «La sal en el Mediterráneo»; Armando Alberola Romá, «En torno a la explotación de la sal en tierras valencianas durante la época moderna", dins J. L. Castellano Castellano i M. L. López-Guadalupe Muñoz, eds., Homenaje a don Antonio Domínguez Ortiz, Publicaciones de la Universidad de Granada, Granada, 2008, I, pp. I-I9. Antonio Espino LópeZ, «La climatología y el negocio de la sal en la Ibiza del siglo XviI", Revista de Historia Moderna. Anales de la Universidad de Alicante, 33 (2015), pp. 243-262.

27. Fernand Braudel i Ruggiero Romano, Navires et merchandises à l'entrée du port de Livourne, I547-I6II, Armand Colin, París, I95I, p. 47.

28. Cavanilles, Observaciones, I, p. 37. 
tació va començar a les acaballes dels anys seixanta del segle Xviır. No obstant això, les característiques d'aquesta sal — més forta i fosca que la de la Mata-, un preu assequible i la facilitat per a carregar-la en els vaixells gràcies a un moll de fabrica nova, van convertir Torrevella en un referent saliner.

M'interessa destacar molt breument les tasques de cristal.lització, recollida i transport de la sal des de les salines fins als punts d'embarcament. Cronistes, tractadistes, viatgers il.lustrats i persones interessades en general, els van dedicar espais significatius en les seues obres i no van resistir la temptació de comparar-les amb les faenes pròpies de l'agricultura, ja que seguien unes pautes similars a les d'aquesta i, fins i tot, empraven una terminologia anàloga. Aquesta circumstància ha fet que les recollides de sal puguin ser emprades com a proxy data per a esbrinar les oscil.lacions climàtiques, ${ }^{29}$ atès que els esdeveniments hidrometeorològics influeixen en els temps de recollida i, òbviament, en les quantitats collides. ${ }^{30}$ I encara que la naturalesa fora «el único artífice que elabora este producto [la sal]», requeria "[el] auxilio del hombre para su extracción y recolección». ${ }^{31}$ Es tractava, doncs, d'un procés perfectament reglat en el qual cadascun dels protagonistes — naturalesa o home - actuava en el moment precís, en relació amb el qual trobem al.lusions a «collites anuals» amb les seues corresponents «tem-

29. En aquest sentit, devem al professor José Manuel Pérez García un estudi precursor, ja que inclou les dades de producció de sal en A Lanzada des de I75I i les relaciona amb les oscillacions meteorològiques, en la seua ja llunyana obra Un modelo de sociedad rural de Antiguo Régimen en la Galicia costera: la peninsula de Salnés (jurisdicción de La Lanzada), Universidad de Santiago de Compostela, Santiago de Compostel.la, 1979. Vegeu, igualment, Pierre Jeannin, «Le Marché du sel marin dans l'Europe du Nord du XIve aux XviII ${ }^{e}$ siècles», dins M. Mollat, dir., Le rôle du sel, pp. 8o-8r. Espino López, «La climatología y el negocio de la sal».

30. Madoz, per exemple, comenta que les grans i continuades pluges de l'any 1794 van provocar una entrada d'aigua tres vegades superior a l'habitual a la llacuna de la Mata, la qual va impedir l'evaporació de la sal i, per tant, la seua producció al llarg de dos anys; Pascual Madoz, Diccionario geográfico-estadístico-histórico de Alicante, Castellón y Valencia, Institució "Alfons el Magnànim», València, 1982, II, pp. 22-23.

3I. Ibidem, p. 22. 
porades», que s'iniciaven amb l'estació càlida, coincidint amb la marea alta de les salines, i concloïen amb el començament de les pluges tardorenques. ${ }^{32}$

La inundació de les salines tenia lloc durant els mesos hivernals per l'acció combinada de les precipitacions i la penetració de l'aigua del mar. Amb les calors primaverals s'iniciava l'evaporació gradual de l'aigua, que propiciava, a la primeria de maig, que la sal començara a quallar-se. Arribat el mes d'agost, les aigües estaven pràcticament evaporades i la sal, com deia Madoz, "congelada, firme, sólida y perfectamente granada», de manera que la seva superfície restava com un tauler de tal solidesa que hi podien transitar homes, cavalleries i, fins i tot, carruatges sense risc de trencament. ${ }^{33}$

En aquests moments, quan la naturalesa acabava el procés de cristallització de la sal, l'home començava el treball d'extracció i trasllat de la sal fins al punt d'embarcament. Vargas Ponce precisa que la «collita» de la sal eivissenca, en les seues varietats roja i blanca, es duia a terme durant el mes d'agost, després d'haver-la "criat» en les tretze basses de què es disposava, i posteriorment es conduïa amb els naturals del país als tres carregadors habilitats per a açò, coneguts com Roxo, de Llevant i de Ponent o Cova Llarga. ${ }^{34}$ Cavanilles, en referir-se a la Mata, denomina «obrers» els treballadors que, equipats amb una destral, penetraven en les salines per a trencar la sal a colps i separar-la en blocs. ${ }^{35}$ Preferien l'existent en la part compresa entre les ribes i el centre de les salines per la seua major neteja i menor gruixària i duresa. Una vegada acabada aquesta tasca, els blocs eren carregats en cavalleries i transportats a les denomina-

32. Alberola Romá, La sal en el Mediterráneo occidental, pp. I6o-i6i; Alberola Romá, «En torno a la explotación de la sal», pp. I6-19.

33. Madoz, Diccionario, iI, pp. 22-23 i I66. CaVAnilles, Observaciones, II, pp. 294296.

34. José Vargas Ponce, Descripciones de las islas Pithiusas y Baleares, Imprenta de la Viuda de Ibarra, Hijos y Compañía, Madrid, I787; reedició facsímil amb estudi preliminar de Isabel Moll Blanes, Calamus Scriptorius, Barcelona, 1983, pp. 7-IO. Vegeu així mateix Joan Amades, Costumari català. El curs de l'any, Salvat, Barcelona, 1989, IV, pp. 502-504.

35. Cavanilles, Observaciones, II, p. 296. 
des «eres de la sal», on un mestre de fabrica dirigia les operacions per a conformar grans munts que semblaven barraques i que es cobrien amb arena per a protegir-los de la intempèrie fins que els comerciants tancaven els tractes. A partir d'aqueix moment, la sal es traslladava en carros fins al moll i es carregava en vaixells. Lús habitual de cabassos i sàrries en aquesta feina, i les consegüents limitacions de càrrega i temps, van fer que tant Cavanilles com Vargas Ponce recordaren que la utilització de carretons o carretes, a més de convenient per a fer més rendible l'esforç, estava establert per les corresponents instruccions o ordenances. ${ }^{36}$

El treball del saliner era ardu, es remunerava en metàllic i en espècie i no estava exempt de riscos per a la salut, ja que amb relativa freqüència es contreien les febres tercianes, pròpies dels terrenys entollats. Per açò la saviesa popular va encunyar algun que un altre tòpic sobre aquest tema amb la seua conseqüència corresponent. Així, era una creença molt arrelada que la sal consumia les persones i les tornava tísiques i, per exemple, a les illes Balears quan es volia desitjar algun mal a algú, era habitual enviar-lo, figuradament, "a Eïvissa a portar sal», tal com comenta Joan Amades en el seu Costumari. ${ }^{37}$ En aquest sentit, vull cridar l'atenció sobre l'interès i l'aprofitament que ofereix la consulta dels denominats costumaris, els quals arrepleguen, dia a dia i mes a mes, tot el santoral, amb les seues corresponents aplicacions a la vida quotidiana. El recurs al ja esmentat de Joan Amades no sol defraudar. I encara que en relació amb el cas que ens ocupa presta una atenció especial als quefers duts a terme en les salines eivissenques, ${ }^{38}$ els seus comentaris són perfectament aplicables a les salines litorals valencianes, com també ho són els que Vargas Ponce fa pels volts de 1787 , referits així mateix a les primeres. ${ }^{39}$

36. Ibidem, II, pp. 294-296. A Eivissa els saliners portaven la sal a coll o al llom de les mules; cf. Vargas Ponce, Descripciones de las islas Pithiusas, p. 7.

37. Amades, Costumari català, Iv, p. 503.

38. Amades recull la festivitat de Sant Ignasi d'Acevedo, molt venerat per la gent del mar, que se celebra el is de juliol, quan donen començament els treballs en les salines; Amades, Costumari català, IV, pp. 502-504.

39. Vargas Ponce, Descripciones de las islas Pithiusas, pp. 7-IO. 
En tots els casos, a més d'emprar-se una terminologia molt semblant a la de l'agricultura, se sol destacar el caràcter comunitari del treball, que congregava, amb cançons paregudes a les de les feines agrícoles, no solament bona part dels camperols que vivien als voltants de les salines, sinó també els residents en llocs més distants. En el cas d'Eivissa, la recollida de sal ocupava la pràctica totalitat de la població illenca i pel que fa, per exemple, a la Mata era corrent, a les acaballes del segle XviII, trobar ocupades en aquestes tasques gent procedent de Guardamar, Elx, Mutxamel, Crevillent, Elda, Oriola i Alacant, situació que va perdurar en les centúries següents.

\section{4. "Faent camins dubtosos per la mar»: una navegació arriscada i perillosa}

El Mediterrani és, aparentment, un mar tranquil; però això no vol dir que la navegació no puga tornar-se atzarosa, sobretot a l'hivern. Disposem de suficients exemples del comportament agressiu i perillós dels agents meteorològics durant aquesta estació en l'època que comentem. També coneixem l'existència de tradicions i comportaments quasi immutables que, segons si es tractava de l'estiu o de l'hivern, dividien el curs de la vida quotidiana en aquest mar en dues fases ben diferenciades que es repetien rutinàriament any rere any..$^{40}$

Així, durant el segle XVI, cap a la segona setmana de setembre es donava per finalitzat l'estiu al Mediterrani i a partir de la tercera començava a comptar el temps d'hivern, que s'allargava fins a abril, quan l'arribada de la primavera — «esplendorosa i humida», «encara que curta i ventosa» - feia esclatar la floració d'ametlers i oliveres i donava pas al bon temps. En aquest període de la història, l'hivern mediterrani feia por, ja que començava prompte i concloïa tard. Durant aquesta estació, la navegació es veia molt afectada perquè el mar es tornava «hostil», per la qual cosa la solució més eficaç va consistir a obrir o tancar als vaixells unes

40. Braudel, El Mediterráneo, i, p. 324 i seg. 
invisibles «portes» durant els solsticis i equinoccis. En l'antiguitat el tràfic marítim es paralitzava entre octubre i abril. Açò obligava a recloure les embarcacions de guerra en els ports com a mesura precautòria i a llicenciar les tropes. Principiava, com apunta Braudel, la «stagione horrida», duríssima per a tothom, sense distinció de persones, animals o vegetals. I arribava el temps del fred glacial, de les pluges constants dia i nit, de les revingudes dels rius i les inundacions, de les nevades sobtades, de les borrasques i els temporals marítims, dels naufragis. Eren moments de replegament de les vides, de paràlisi quasi total, sobretot al camp, molt afectat en la seua quotidianitat. ${ }^{4 \mathrm{I}}$ La relació de desgràcies i devastacions conseqüència de la inclemència dels elements en el medi rural és àmplia al llarg dels segles moderns en tot l'àmbit mediterrani i, per extensió, en l'europeu. No oblidem, torno a recordar-ho, que eren els moments de la petita edat del gel. ${ }^{42}$

Manuel Peña, en el ja llunyà I Congrés d'Història Moderna de Catalunya, l'any 1984, va fer una aproximació a la climatologia catalana del segle XVII emprant fonts narratives manuscrites referides a l'entorn de Barcelona i la plana de Vic. Amb prudència i les lògiques cauteles, va establir una caracterització que no s'allunyava del model conegut per a Europa i que estudis posteriors han ratificat. ${ }^{43}$ La duresa hivernal va dominar les dues primeres dècades; entre I62I i I640 les baixes temperatures hivernals es van veure ocasionalment interrompudes per fortes calors estiuenques, encara que l'hivern de I623-1624 va ser molt cruel i es va allargar fins a l'abril, amb neu abundant a l'Empordà i l'Ebre gelat a Tortosa. Durant els vint anys següents, la cruesa termomètrica va re-

4I. Ibidem, p. 325; Armando Alberola Romá, "Clima y guerra en tiempos de Cervantes y Shakespeare. De la Felicísima jornada de Lepanto (I57I) a la debacle de la Grande y felicísima Armada contra Inglaterra (I588)», dins J. M. González, J. M. Ferri i Ma C. Irles, eds., Cervantes-Shakespeare I616-2016. Contexto. Influencia. Relación, Reichenberger, Kassel, 2017, pp. 50-70.

42. Alberola Romá, Los cambios climáticos, pp. 49-54.

43. Manuel Peña Díaz, "Aproximación a la climatología en la Cataluña del siglo XvII", dins I Congrés d'Història Moderna de Catalunya, Universidad de Barcelona, Barcelona, 1984, I, pp. 255-265. 
tornar i una onada de fred va assotar el nord-est peninsular durant l'hivern de I64I-I642. La tardor següent, molt freda, va donar pas de nou a un hivern sever, seguit de gelades que van castigar tota la costa mediterrània. L'estiu de l'any I650 va resultar excepcionalment calorós, malgrat que l'Ebre s'havia gelat de nou un any enrere; per contra, el gener i el febrer de I652 van ser molt durs. Entre els anys I660 i I680 va haver-hi una relativa i breu millora de les temperatures, amb l'excepció dels severs hiverns dels anys I667-I670, però a partir de I679 i amb el mínim de Maunder en ple apogeu, les condicions climàtiques van tornar a extremar-se a Catalunya, igual que a Europa, amb un predomini d'hiverns durs i estius frescos. Una onada de fred es va deixar sentir entre I663 i I668 amb nevades molt intenses, les quals es repetiren els anys I678-I679 i en la dècada dels huitanta. Al sud, en terres valencianes, l'anàlisi de diversos dietaris ha desvetllat que les circumstàncies van ser quasi idèntiques en aquest període de la història. ${ }^{44}$

En la centúria següent, estius molt calorosos van conviure amb hiverns duríssims, tal com ha estudiat Mariano Barriendos emprant documentació municipal i, sobretot, el diari del baró de Maldà, un autèntic pou d'informació meteorològica que li va permetre caracteritzar amb precisió la peculiar seqüència climàtica ja esmentada, que es va estendre entre els anys I760 i I8Io i va ser batejada, amb justícia, com a "oscilllació Maldà». ${ }^{45}$ Altres estudis complementen els resultats de Barriendos i permeten establir amb exactitud les variacions climàtiques a la conca mediterrània occidental durant el segle XVIII. ${ }^{46}$

44. Alberola Romá, "Clima, desastre y religiosidad popular»; Alberola Romá, «La Petita Edat del Gel en terres valencianes», pp. 28-30.

45. Barriendos i Llasat, «El caso de la anomalía "Maldà"».

46. Alberola Romá, Los cambios climáticos, pp. 179-248; Armando Alberola RomÁ, «Anomalías hidrometeorológicas, prevención de riesgos y gestión de la catástrofe en la fachada mediterránea española durante el siglo XvıII", dins A. Alberola Romá, coord., Clima, naturaleza y desastre. España e Hispanoamérica durante la Edad Moderna, Publicacions de la Universitat de València, València, 20I3, pp. 8I-97; Armando Alberola RomÁ, «Risc natural, desordre climàtic i catàstrofe al Mediterrani espanyol durant el segle xviII", Afers. Full de Recerca i Pensament, 69 (20II), pp. 337354; Armando Alberola Romá, Quan la pluja no sap ploure; Armando Alberola 
Però tornem al mar; als "camins dubtosos per la mar», que deia el valencià Ausiàs March en el seu poema «Veles e vents». Des de mitjan segle XVI és indubtable que la navegació va intentar sobreposar-se a l'aturada hivernal gràcies a les millores tècniques introduïdes en les embarcacions i en l'art de navegar, però, en qualsevol cas, açò no garantia que l'hivern mediterrani no estigués ple de naufragis. ${ }^{47}$ Les tempestats estaven a l'ordre del dia i de la nit i, a diferència del període estival, el risc i la durada de les singladures s'incrementaven; per açò a partir d'octubre el nombre de viatges es reduïa. Això no vol dir que es renunciés a navegar; ara bé, es feia sempre en distàncies curtes i amb cels nets, tot i coneixent els perills i les amenaces. Era raó suficient perquè la navegació comercial minvés en aquesta època, encara que els vaixells més grans i capaços de fer front als temporals s'atrevien a solcar les aigües mediterrànies, ja que, precisament, el risc reportava beneficis importants.

D'altra banda, la guerra de galeres es desaconsellava a l'hivern, ja que el poc calat d'aquestes embarcacions les deixava molt exposades a borrasques i temporals. Vegeu dos exemples d'aquest fet: l'intent de la presa d'Alger en octubre de I54I i el desastre de la badia malaguenya de La Herradura el mateix mes, però de 1562. En el primer cas, Carles V va patir un gran fracàs per haver triat molt malament l'estació; en el segon, una imprevista i gran tempesta va engolir el ig d'octubre de 1562 quasi tota la flota de galeres manada per Don Juan de Mendoza y Carrillo, la qual, amb base a Sardenya, tenia per objectiu la neteja de corsaris de les costes peninsulars. En a penes tres hores, un canvi de vent sobtat va alçar una tempestat de conseqüències dramàtiques: vint-icinc de les vint-i-vuit galeres que integraven la flota van anar a pic i van morir cinc mil persones entre comandaments, soldats, tripulants, remers i passatgers. Estudis recents atribueixen el naufragi al pas d'un cicló extratropical que devia penetrar des de l'Atlàntic al Mediterrani

RoMÁ, «El clima "trastornat": sequera, temporals, riuades i inundacions a Catalunya i el País Valencià a les acaballes del segle xvIII", Estudis d'Història Agrària, 23 (201020II), pp. 3OI-3I8.

47. Braudel, El Mediterráneo, I, pp. 328-329. 
per l'estret de Gibraltar i, posteriorment, ja convertit en una gran borrasca, es devia dirigir cap a l'interior alçant forts vents del sud-oest que van provocar violentes ones d'entre sis i nou metres. ${ }^{48}$ En aquest context, és clar que la cèlebre batalla de Lepant del 7 d'octubre de I57I va tindre lloc en un moment atmosfèric molt delicat, amb les portes de l'hivern acabades d'obrir, amb el risc que açò suposava. No puc estendre'm gaire, però eren ben coneguts els temporals que a l'hivern sacsejaven les aigües de l'Adriàtic i, per extensió, les del Jònic, on es troba el golf de Lepant. Coneixem bé el desenvolupament del combat, que va acabar amb la desfeta total dels turcs; ${ }^{49}$ també les circumstàncies de tipus meteorològic $c^{50}$ de la que Cervantes va considerar «la más memorable y alta ocasión que vieron los pasados siglos, ni esperan ver los venideros»..$^{\text {s }}$

Ja he dit abans que són abundants les referències a naufragis en el Mediterrani durant el segle XVI, recollides per Braudel en el primer volum de la seua gran obra. ${ }^{52}$ Estalvie als lectors la seva relació exhaustiva, però sí que vull recordar que els canviants vents propis del Mare Nostrum feien «bullir el mar com a cassola en forn», com va escriure

48. José Ma Sánchez-Laulhé i Ma Carmen Sánchez de Cos, «Meteorología en el naufragio de la flota espańola de galeras en La Herradura (Almuñécar) en 1562", Boletín de la Asociación Meteorológica Española, 38 (octubre 20I2), pp. 28-33. $\mathrm{M}^{\mathrm{a}}$ del Carmen Calero Palacios, Naufragio de la Armada Española en la Herradura (Almuñécar). Aportación Documental, Diputación de Granada, Granada, 20I2. Cesáreo Fernández Duro, Armada española desde la unión de Castilla y Aragón, Est. Tipográfico Sucesores de Rivadneyra, Madrid, I896, II, p. 48.

49. Hugh Bicheno, La batalla de Lepanto, I57I, Ariel, Barcelona, 2005; Braudel, El Mediterráneo, iI, pp. 6oo-6o8; Luis Cabrera de Córdoba, Historia de Felipe II, rey de España. Imprenta, Estereotipia y Galvanoplastia de Aribau y Ca, Madrid, I876I877, II, llibre IX, caps. XXIII-XXVI.

50. Alberto Linés Escardó, "El tiempo atmosférico en el siglo de Felipe II», dins Felipe II y su época. Actas del Symposium, I al 5-IX-I998, San Lorenzo de El Escorial, Real Centro Universitario Escorial-María Cristina, I998, II, pp. 673-695. Alberola Romá, "Clima y guerra en tiempos», pp. 57-62.

51. Pròleg a la segona part de El Quijote (I6I5). Referències a la batalla en el capítol xxxix, «Donde el cautivo cuenta su vida y sucesos».

52. Vegeu la nota 47 . 
Ausiàs March, i el tornaven enormement perillós. Mateo Alemán descriu amb gran realisme la violenta i llarga tempesta patida per Guzmán de Alfarache mentre navegava, a l'hivern, des de Gènova fins a la península Ibèrica. Travessant el golf de Lleó i enmig d'un terrible temporal de pluja i vent, va ser necessari assegurar el passatge i penjar, arribada la nit, els fanals de borrasca per seguretat i per a evitar mals majors. ${ }^{53}$ Durant el segle XVIII també són nombroses en diaris i gasetes les notícies d'embarcacions enfonsades a prop de la costa com a conseqüència de fortíssimes tempestats que alçaven ones de gran alçada.

Per tant, els mesos hivernals eren forçosament pacífics i les guerres passaven a un estadi de latència que els estats aprofitaven per a cercar aliances, preparar converses de pau o dissenyar noves estratègies i plans d'atac. Arribada la primavera, el Mediterrani continuava sent un mar poc fiable. Abril era un mes complex, però un dels més actius de l'any; no debades, les assegurances marítimes augmentaven considerablement entre abril i maig. Però quan l'estiu irrompia, el tràfic marítim s'activava en totes les rutes, ja que els vents saharians porten bon temps i, sobretot, estabilitat atmosferica. En l'Egeu els vents bufen regularment de nord a sud entre maig i octubre, fins a l'arribada de les primeres tempestes tardorenques. Per açò les singladures es feien més ràpides i segures i se’n podia preveure la durada. També la guerra, en totes les seues formes, tornava amb l'estació estival. I, per descomptat, tornaven el comerç i les relacions de tot tipus de llarg a llarg de la conca marítima.

\section{Pous de neu: el comerç del fred}

Arribats a aquest punt, m'agradaria esmentar una de les activitats econòmiques més interessants i rendibles de les desenvolupades a les terres mediterrànies a l'edat moderna, estretament vinculada al fred hivernal. Em refereixo a la construcció de pous i geleres i a la recollida, l'emma-

53. Mateo Alemán, Segunda parte de la vida de Guzmán de Alfarache, atalaya de la vida humana [...], Sebastián de Cormellas, Barcelona, I605, llibre II, capítol IX, pp. I42-I44. 
gatzemament i la venda posterior de la neu caiguda al llarg de l'hivern; un negoci que, com l'espia de John Le Carré, va sorgir del fred. ${ }^{54}$ Sobre aquests tres eixos va gravitar, fins a l'aparició del gel industrial, una ocupació que ha deixat una petjada profunda en la història econòmica i cultural, així com en el paisatge. Vinculada als rigors hivernals, però també als cremors estivals, està fora de dubte la influència que el caràcter extremat del clima patit al llarg de la petita edat del gel va tindre en la consolidació d'aquest remunerador negoci durant els segles moderns. 55

Des de l'antiguitat, la neu va ser utilitzada per a conservar els aliments, refredar les begudes, fabricar gelats o remeiar dolences i malalties, i durant molts segles va ser un producte de consum reservat a les classes privilegiades. ${ }^{6}$ Però, arribats al cinc-cents, el gaudi de la neu es va popularitzar i ja no va conèixer distincions socials en cap lloc. Tampoc de cap a cap de la península Ibèrica. A la família reial, la noblesa, els alts funcionaris i els diplomàtics, els agradaven les begudes fredes, els sorbets i els gelats en la seua vida diària i, sobretot, en les seues festes. Al clergat també li encantava tenir totes aquestes «delícies» en les seues taules i, de la mateixa manera que la noblesa, posseïa pous propis per a emmagatzemar-les. ${ }^{57}$ Però la generalització de la ingesta de neu entre les classes populars va acabar per convertir-la en un article de primera necessitat i

54. Alberola Romá, Los cambios climáticos, pp. I30-I40.

55. Bartolomé Barceló Pons, «El comercio de la nieve en Mallorca», Boletín de la Cámara Oficial de Comercio, Industria y Navegación de Palma de Mallorca, LIX, 623 (1959), pp. 46-52. Horacio CAPEL, «Una actividad desaparecida de las montañas mediterráneas: el comercio de la nieve», Revista de Geografía, IV, I (I970), pp. 5-42; Horacio CAPEL, "El comercio de la nieve y del hielo», Biblio 3 W. Revista Bibliográfica de Geografía y Ciencias Sociales, I6 (1997); Horacio CaPEL, «Medicina y clima en la España del siglo xviII", Revista de Geografía, vol. xxxII-XXXIII (I998-1999), pp. 79-I05. Fernando Beltrán Cortés, Apuntes para una historia del frío en España, CSIC, Madrid, 1983.

56. Braudel, Civilización material, i, pp. I9I-I92; Xavier de Planhol, L'eau de neige. Le tiède et le frais. Histoire et géographie des boissons fraîches, Fayard, París, 1995.

57. Sobre els hàbits alimentaris, resulten imprescindibles els treballs de María de los Ángeles Pérez Samper; vegeu, per exemple, entre d'altres, María de los Ángeles Pérez SAMPer, Mesas y cocinas en la España del siglo XVIII, Trea, Gijón, $20 I I$. 
el seu proveïment va esdevenir una preocupació per als governants. Pel que fa a les seues virtuts terapèutiques, la neu era emprada per a tractar cremades, congestions, hemorràgies, mal de cap i, sobretot, febres; però també se subministrava als afectats per la pesta. ${ }^{58}$ En la façana mediterrània espanyola va ser utilitzada amb profusió en forma de llimonada per a tractar els afectats de febres tercianes, malaltia que irrompia tots els anys amb les calors estivals. 59

Els procediments per a generar fred, en aquest període històric, es reduïen a dos: el gel i la neu. El primer s'obtenia després de derivar cursos d'aigua en els mesos de desembre i gener cap a basses i estanys perquè es congelaren amb les baixes temperatures hivernals. Posteriorment, els grans blocs resultants es tallaven a trossos i s'emmagatzemaven en dipòsits propers a força de capes separades amb palla i branques perquè resistiren bé fins a l'estiu. El procés era complex perquè exigia, a més de conduccions i reservoris, temperatures baixes i constants, per açò era habitual en les àrees més fredes del continent europeu. En terres catalanes es troben bons exemples d'aquesta tècnica d'elaboració de gel a l'Avencó, al massís del Montseny, i en l'altiplà del Moianès, a la comarca del Vallès Oriental. ${ }^{60}$

El segon procediment era més senzill perquè evitava la fase de congelació en basses, encara que obligava a mobilitzar un gran nombre de braços tan aviat com es produïen les nevades. Tan bon punt queia, la neu era arreplegada per quadrilles d'homes que, amb pales i aixades, la introduien en sacs i cabassos que traslladaven mitjançant cavalcadures fins a prop dels pous, on formaven grans munts que posteriorment introduien al seu interior seguint un meticulós protocol controlat per un capatàs que perseguia la seua perfecta conservació fins a l'estiu. També

58. Capel, «Una actividad desaparecida», pp. 9-IO.

59. Armando Alberola Romá, "Una enfermedad de carácter endémico en el Alicante del siglo XviII: las fiebres tercianes», Revista de Historia Moderna. Anales de la Universidad de Alicante, 5 (1985), pp. I27-I40.

6o. Jaume Dantí, Cinta Cantarell i Pere Cornellas, Pous de glaç al Vallès Oriental, Granollers, Consell Comarcal El Vallès Oriental / Museu de Granollers, 2007. CAPEL, «Una actividad desaparecida», pp. I7-2I. 
podien efectuar aquesta tasca els mateixos treballadors, que empraven per a açò recipients a manera de motxilles o una espècie de civeres que manejaven en grup. El treball era molt dur. En general, els pous tenien el fons i les parets recoberts amb matolls i branques d'arbre, encara que també n'hi havia de revestits de maçoneria o de fileres de pedra perfectament aparellada. Arribat l'estiu, el gel estava llest per a proveir les localitats que ho sol-licitaren o que tingueren establida alguna relació contractual — normalment un arrendament - que garantira el transport i subministrament, tal com succeïa en la pràctica totalitat de ciutats i viles espanyoles.

El gel, tallat en blocs que eren embolicats amb mantes i sacs i coberts amb palla perquè no es fonguera, es traslladava de nit, generalment en cavalleries i carros, fins als centres de distribució i consum. Allí un funcionari municipal, després de revisar les càrregues i comprovar que s'ajustaven al contracte, autoritzava el seu repartiment des d'establiments públics o mitjançant venedors ambulants. Les grans ciutats, a més de disposar de pous en les muntanyes pròximes per a garantir-se una bona provisió de neu, també van construir dipòsits en el propi casc urbà per tal de disposar de reserves suficients. Catalunya i sobretot Barcelona, gran consumidora de begudes fredes i gelats, van organitzar un sistema a gran escala de pous i reservoris que permetien un proveïment estable de neu. ${ }^{61}$ Mallorca va sostenir un important, encara que irregular, comerç marítim amb les properes illes d'Eivissa i Menorca, que descansava en la dotzena de cases de neu situades en les ombries de les serres septentrionals. València i Alacant, ben aprovisionades des de les muntanyes properes gràcies a una eficaç xarxa de pous, van liderar, juntament amb Barcelona, el consum de neu/gel per habitant en aquesta època. ${ }^{62}$

6I. Jaume Dantí, «Una pluriactivitat mediterrània. L'abastament de neu i glaç a Barcelona (segles XVI-XVIII)", dins M. Á. Pérez Samper, coord., La Mediterrània a l'època moderna, pp. I3-31.

62. Horacio CAPEL, «Una actividad desaparecida», pp. 26-28; José Mallol FerRÁNDIZ, Alicante y el comercio de la nieve en la edad moderna, Universidad de Alicante / Caja de Ahorros Provincial, Alacant, I989. 
En les muntanyes valencianes aquesta activitat representava per als camperols un complement de la feina de casa, ja que durant l'hivern, quan sobraven braços per a l'agricultura, s'ocupaven d'arreplegar la neu, dipositar-la en pous i cobrir-la amb mates i branques d'arbre per a conservar-la fins a l'estiu i traslladar-la a les diferents poblacions. ${ }^{63} \mathrm{La}$ situació era molt semblant en altres llocs de la geografia montuosa espanyola: des de Mallorca fins a la serra d'Espuña (Múrcia), passant per València, Catalunya, les serralades bètiques i penibètiques andaluses, les muntanyes aragoneses i navarreses, Galícia, la Meseta, Madrid i el seu entorn. ${ }^{64}$

L'abundant i generalitzat consum, a preus relativament assequibles, fins a l'aparició del fred industrial, va convertir la neu en un subjecte fiscal que proporcionava importants ingressos a les arques de la monarquia i de les hisendes locals. També va fer que la seua comercialització es plantejara molt ràpidament com un bon negoci. Almenys així ho va entendre el català Pau Xarquies, qui en 1607 va obtenir el monopoli per a vendre gel i neu a Madrid i va arribar a controlar bona part dels pous i els llocs de venda existents en la Cort; encara que al cap de poc va haver de fer front a una feroç competència illlícita que el va obligar a pledejar per a defensar els seus interessos.

Abans he comentat que la dependència d'aquest important comerç respecte de la major o menor disponibilitat de neu sembla inqüestionable; per aquest motiu, diferents autors han fet notar la seua estreta vinculació amb la petita edat del gel. ${ }^{65}$ L'existència de nombrosos pous, neveres, congestes i cases de neu de llarg a llarg de la geografia peninsu-

63. Cavanilles, Observaciones, II, p. I80.

64. Alberola Romá, Los cambios climáticos, pp. I35-I36.

65. Vegeu, entre d'altres, Barceló Pons, «El comercio de la nieve»; CAPEL, «Una actividad desaparecida»; Mallol Ferrándiz, Alicante y el comercio de la nieve; Jorge Cruz Orozco i José María Segura Martí, El comercio de la nieve. La red de pozos de nieve en las tierras valencianas, Generalitat Valenciana, València, I996; José Quereda i Emilio Овгог, «Glacières et puits á neige dans la région de Castelló de la Plana: indicateurs paléoclimatiques phenologiques», Révue Géographique des Pyrénées et du Sud-Ouest, 6I, 2 (1990), pp. 285-304; Elisa Cristóbal i Carlos Martín Escorza, «El comercio y los pozos de nieve en Calahorra durante los siglos XviI a XIX y su relación 
lar requereix com a mínim una reflexió, sobretot pel que fa a les càlides terres banyades pel Mediterrani. Sobretot tenint en compte que molts d'aquests receptacles es localitzen, des de la perspectiva climàtica actual, en altituds cridanerament baixes.

Així, per exemple, dels 300 pous de neu inventariats per Cruz i Segura per al territori valencià, 46 - una mica més del $15 \%$ - es troben per sota dels 600 metres; i d'aquests, 22 s'alcen entre els 400 i els 200 metres i 7 estan per sota d'aquesta última altitud. I no cal parlar dels dipòsits aïllats, que podrien estar justificats per a satisfer una demanda local, ja que tots ells formaven part d'un comerç integrat que cobria una àmplia superfície. En les condicions climàtiques actuals aquests pous manquen de sentit, ja que si a 800 metres és difícil contemplar una nevada, per sota dels 200 és, simplement, impossible. ${ }^{66}$ Per aquest motiu, l'existència d'un nombre tan gran de dipòsits per a conservar la neu ha d'entendre's com el reflex d'una realitat climàtica ben diferent de l'actual i com una prova més d'aquests contrastos que podem trobar a l'àmbit mediterrani.

\section{Més paisatges: el desastre, la por, el patiment i la malaltia}

Al Mediterrani també trobem paisatges on, de tant en tant, el desastre, la por, el patiment i la malaltia cobren gran protagonisme. Ho resumiré. Terratrèmols i erupcions volcàniques han estat presents - $\mathrm{i}$ ho estan encara - en totes les èpoques en aquest àmbit i, per tant, podríem dir que també formen part de la seua identitat. Els primers són fenòmens geològics imprevisibles, amb un alt grau de destrucció, que poden ocasionar nombroses víctimes i trencar les societats, deixant-les en un estat d'absoluta provisionalitat. El fet d'ignorar quina era la causa que els produïa, provocava en la gent un temor irrefrenable i un gran senti-

con los cambios climáticos», Kalakorikos, 8 (2003), pp. I5I-I68. Alberola Romá, «La Petita Edat del Gel a terres valencianes», p. 32.

66. Cruz Orozco i Segura Martí, El comercio de la nieve, pp. 3i-36. 
ment de culpabilitat. Pel que fa a les erupcions volcàniques, la història del Mediterrani ha deixat constància escrita — també imatges — d'erupcions volcàniques amb conseqüències terribles. Paisatges de destrucció, amb camps i infraestructures de tot tipus arrasades, poblacions soterrades per la lava i les cendres, molta por, mort, sensació social d'abandó a la seua sort. Els nostres ulls es dirigeixen, indefectiblement, cap a la península Itàlica, territori molt sensible a terratrèmols i erupcions, però cal no oblidar que a la península Ibèrica també es van patir moviments sísmics amb conseqüències importants, com els que van sacsejar la Catalunya Nord als segles XIV i XV, ben estudiats per Riera Melis i el seu grup, ${ }^{67}$ els d'Andalusia durant l'edat moderna, ${ }^{68}$ el terratrèmol d'Estubeny-Montesa ${ }^{69}$ en 1748 en terres valencianes, amb quasi cent poblacions afectades, o, sens dubte, el pitjor i el més destructiu de tots: el de Lisboa de l'i de novembre de I755, amb diferents graus d'afectació a la pràctica totalitat de la península Ibèrica. ${ }^{\circ}$ En tots els casos, es tracta del

67. Carme Olivera, Esther Redondo, Jêrome Lambert, Antoni Riera Melis i Antoni RocA, Els terratrèmols del segles XIV $i$ XV a Catalunya, Institut Geogràfic de Catalunya, Generalitat de Catalunya, Barcelona, 2006; Pierre VILAR, «Le declin catalan du Bas Moyen Age. Hypothèses sur sa chronologie», Estudios de Historia Moderna, vol. 5 (1956-1959), pp. IO-II.

68. Bernard VinCENT, «Les tremblements de terre dans la province d'Almería (xv-xix siècles)», Annales. E. S. C., Xxix (maig/juny 1974), pp. 57I-586; Bernard VINCENT, "La tierra tiembla en Andalucía. Estudio histórico (ss. XVI-XIX)», dins J. A. González Alcantud i M. González de Molina, eds., La tierra. Mitos, ritos y realidades, Anthropos / Diputación de Granada, Granada, 1988, pp. 44I-452. César Olivera Serrano, Sismicidad histórica del Reino de Granada (I487-I53I), Instituto Geográfico Nacional, Madrid, 1995, monografia núm. I2.

69. Alberola Romá, «No hay resistencia contra el poder de los elementos enfurecidos: el terratrèmol de Montesa-Estubeny del I748", pp. 309-322. Jorge L. Giner-Robles, Pablo G. Silva, Miguel A. Rodríguez-Pascua, R. Pérez López i Armando AlberoLA RomÁ, "Efectos geológicos y arqueológicos producidos por el terremoto de Estubeny de 1748 AD (SE de España)», dins J. A. Álvarez Gómez i F. Martín González, eds., Una aproximación multidisciplinar al estudio de las fallas activas, los terremotos y el riesgo sismico, Ayuntamiento de Lorca, Lorca, 20I4, pp. 155-158.

70. José Manuel Martínez solares, Los efectos en España del terremoto de Lisboa (I de noviembre de 1755), Instituto Geográfico Nacional-Ministerio de Fomento, Ma- 
paisatge del desastre, però també del de la por i el patiment; i la seua «reparació» exigia accions decidides i urgents. Des de la part civil, és a dir, des de l'àmbit politicoadministratiu, calia mobilitzar recursos i ajudes, socórrer els damnificats, enterrar els morts, llevar enderrocs i ruïnes, preparar la reconstrucció, perdonar deutes o condonar temporalment impostos. Però també, des de la part eclesiàstica, a més de donar almoines i atenció humanitària d'urgència, entrava també en acció la cura espiritual mitjançant els mecanismes propis d'una religiositat popular molt arrelada, en la qual rogacions, processons penitencials, misses i similars eren moneda corrent.

Però més que a aquestes qüestions, vull dedicar la meua darrera reflexió a un altre paisatge ben propi del Mediterrani: el de la malaltia i el patiment per les febres tercianes, amb el perill que representaven, i no tan sols des del punt de vista medicosanitari. Malaltia endèmica de la conca mediterrània, les febres tercianes — també anomenades malària o paludisme - van constituir un greu problema en segles passats. Fa ja bastants anys, vaig escriure que el paludisme no va ser, als segles moderns, un viatger de pas que, com la pesta, arrasava poblacions i fugia amb la seua càrrega de patiment i mort. Al contrari, va trobar en el Mediterrani el seu lloc d'assentament, aprofitant les seues planícies i terres baixes inundades, i per açò va convertir-se en un mal endèmic propi d'aquest medi geogràfic, com va assenyalar Braudel..$^{71}$

En el litoral mediterrani peninsular, sobretot en el valencià, el problema adquiriria una gravetat i un dramatisme especial quan, al marge de l'abundància d'àrees deprimides entollades, tant litorals —albuferes - com interiors, el conreu de l'arròs va començar a estendre's ocupant noves terres. Les febres tercianes no van assolir tota la seua dimensió ni van ser considerades com una greu amenaça sanitària fins al I720, any en què el Mediterrani occidental va patir l'última envestida pestífera. Superada, doncs, la coneguda com a "pesta de Marsella», les febres

drid, 200I, monografia núm. 19. Armando Alberola Romá, «El terremoto de Lisboa en el contexto del catastrofismo natural en la España de la primera mitad del siglo xviII", Cuadernos Dieciochistas, 6 (2005), pp. 19-42.

7I. Braudel, El Mediterráneo, i, p. 80. 
tercianes van ocupar el lloc que els corresponia en el catàleg de preocupacions dels habitants de les costes del Mare Nostrum i van arribar a tindre tal protagonisme que un dels seus grans historiadors va proposar denominar el segle XVIII «el segle de les febres». ${ }^{72}$ Durant centúries, la gent havia assumit, amb el fatalisme propi dels mediterranis, que arribat l'estiu apareixia la malaltia i que, indefectiblement, un percentatge significatiu dels qui habitaven a prop de llacunes, marjals o albuferes la contraurien. La mortalitat de les febres tercianes era moderada, però la seua morbiditat era molt elevada, i a aquesta s'afegien les seqüeles invalidants que ocasionava en l'organisme humà, que quedava molt afectat per a desenvolupar els importants treballs agrícoles del període estival. A València, l'ampliació de la superfície dedicada al cultiu de l'arròs, malgrat les limitacions legals vigents des de l'època medieval i incrementades en el segle XvIII, va contribuir a aguditzar aquest problema sanitari. ${ }^{73}$ Cavanilles va qualificar com a "perilloses» mig centenar de poblacions valencianes per la seua proximitat a arrossars o a àrees deprimides i entollades; destaca en aquest sentit la Ribera de Xúquer, recinte fangós travessat per infinitat de canals que «viciaven l'atmosfera». ${ }^{74}$ Especialment bel.ligerant amb l'ampliació in-

72. José Luis Peset, «Epidemias y sociedad en la Espańa del fin del Antiguo Régimen", dins V Congreso Nacional de Historia de la Medicina. Homenaje al profesor Pedro Lain Entralgo, COIMOF, Madrid, I977, I, p. 46.

73. Vegeu, entre d'altres, Mariano i José Luis Peset, Muerte en España. Política y sociedad entre la peste y el cólera, Seminarios y Ediciones, Madrid, I972. Enric Mateu Tortosa, Arroz y paludismo. Riqueza y conflictos en la sociedad valenciana del siglo XVIII, Alfons el Magnànim, València, 1987. Alberola Romá, Catástrofe, economía, pp. 236-273. V. Olmos Tamarit, coord., Arròs, prosperitat i malaltia, número monogràfic d'Afers. Fulls de Recerca i Pensament, I6 (200I). Pablo Giménez Font, Las transformaciones del paisaje valenciano en el siglo XVIII. Una perspectiva geográfica, Institució Alfons el Magnànim, València, 2008, pp. 284-352.

74. Vegeu totes les reflexions i els comentaris que respecte a aquesta qüestió fa Cavanilles, en Armando Alberola Romá, «De desastres varios y epidemias. El abandono forzoso de poblaciones en el Mediterráneo español durante el siglo XviII», dins M. Rodríguez Cancho i J. P. Blanco Carrasco, coords., Migraciones y movilidad social en la época moderna, Sindéresis, Madrid, 2018, esp. pp. 39-43. 
discriminada del conreu arrosser, l'illlustrat valencià — que va patir la malaltia quan creuava la Ribera durant el seu viatge per terres valencianes- sostenia que calia vetlar per la salut dels qui habitaven en els pobles «malsans i infectes», i encara que no es va atrevir a sollicitar la seua dràstica reducció, sí que va sostenir polèmiques enfront dels qui defensaven la necessitat de mantindre aquest cultiu tan perillós com altament productiu i remunerador.

Enfront de l'agressivitat de les febres tercianes, els remeis podien ser de dues menes: tècnics i mèdics. Els primers obligaven a una gran inversió en sanejament mitjançant la bonificació, amb grans quantitats de terra, i el desguàs de les zones entollades i insalubres. Els segons passaven per l'administració d'escorça de quina als malalts, combinada amb una bona alimentació, jornades laborals raonables i condicions higièniques adequades. Dissortadament, la quina era un producte reservat a les persones amb recursos; a la gent corrent se'ls aplicaven sagnies i, en el millor dels casos, se'ls donava llit en un hospital i se'ls subministrava llimonada, és a dir, aigua de neu amb cítrics. La resta de mesures entraven, simplement, dintre del territori de la utopia i de l'impossible.

Al llarg de l'edat moderna el territori valencià va patir constantment l'escomesa de les febres tercianes, que en no poques vegades es van transformar, de malaltia endèmica, en epidèmica i van ocasionar una gran quantitat de morts. Estan molt ben estudiades les epidèmies corresponents al segle XviII, d'entre les quals destaquen les patides en la segona meitat de segle. Efectes letals va causar la dels anys 1784-1786, que coincidí amb la gran epidèmia que va baixar des de terres catalanes, i les de mitjan anys noranta. ${ }^{75}$

75. Tomás V. Pérez Medina, «Arròs, paludisme i població a la comarca de l'Horta. L'epidèmia de I784", Afers. Fulls de Recerca i Pensament, II-I2 (I99I), pp. I37I5O. Alberola Romá i Bernabé Gil, «Tercianas y calenturas en tierras meridionales valencianas», pp. 95-II2. Rubén Bueno Marí i Ricardo Jiménez Peydró, «Crónicas de arroz, mosquitos y paludismo en España: el caso de la provincia de Valencia (ss. xviII-xx)», Hispania, 70 (20I0), pp. 687-708. Eduardo Bueno Vergara, «La lucha contra la enfermedad en el Alicante del siglo xvinI: el testimonio de los expertos», dins 
A Catalunya, les febres tercianes, acompanyades d'altres malalties, van estar ben presents durant les dècades finals del segle XVIII. ${ }^{76} \mathrm{La}$ declarada a Lleida en 1783 , descrita pel metge Josep de Masdevall, ${ }^{77}$ va ser especialment traumàtica en associar-se a les febres tercianes un brot de febre tifoide; entre els anys I784 i I785 va estendre's per tota la conca mediterrània, on provocà nombroses morts, i després passà a través de l'Aragó a l'interior peninsular, on va ocasionar un terrible desastre demogràfic. La conjunció del paludisme amb altres malalties infeccioses, com ara el tifus, conseqüència de les deficients condicions higièniques de l'època, va ser determinant de la desgràcia. ${ }^{78}$

Aquesta transformació de malaltia endèmica en epidèmica i la seua extensió a quasi totes les regions de l'interior de la península, com la Manxa, Castella la Nova, Andalusia i Extremadura, va trastornar els últims vint anys del segle i va convertir-los, com va escriure Félix Ibánez, que va ser metge d'Huete i Pastrana, en «míseros e infelices con mucha mortalidad, carestía de mantenimiento, cúmulos de pobreza y

A. Alberola Romá, ed., Riesgo, desastre y miedo en la peninsula Ibérica y México durante la Edad Moderna, Publicacions de la Universitat d'Alacant / El Colegio de Michoacán, Alacant, 20I7, pp. 229-253.

76. Kevin Pometti, «Tercianas y epizootias en la Barcelona de 1783-1786. Médicos, poder institucional y percepción social en la Barcelona de las postrimerías del siglo xviII», Pedralbes, 34 (20I4), pp. 433-444; Kevin Pometti, "Tertian Fevers in Catalonia in the Late Eighteenth Centuries: The Case of Barcelona (I783-1786)", dins A. Rodriguez-Morales, ed., Current Topics in Malaria, InTech, Rijeka, 2016.

77. José de MASDEVAlL, Relación de las epidemias de calenturas pútridas y malignas que [...] se han padecido en Cataluña [...], Imprenta Real, Madrid, I786. Juan Riera Palmero, José de Masdevall y la medicina española ilustrada, Universidad de Valladolid, Valladolid, I980 (Acta Histórico-Médica Vallisoletana; x).

78. Vicente Pérez Moreda, Las crisis de mortalidad en la España interior (siglos XVI-XIX), Siglo XXI, Madrid, I980; Vicente PéreZ Moreda, «El paludismo en España a fines del siglo XviII: la epidemia de I786», Asclepio, XXXIv (1982), p. 296; Vicente Pérez MoredA, «Crisis demográficas y crisis agrarias: paludismo y agricultura en España a finales del siglo XviI»", dins Congreso de Historia Rural. Siglos XV al XIX, Casa de Velázquez / Universidad Complutense, Madrid, I984, pp. 333-354. Juan Díaz-Pintado, «Epidemias de paludismo en La Mancha del siglo xviII», Cuadernos de Estudios Manchegos, 2I (199I), pp. 213-247. 
hambre», en les quals la gent menjava el que trobava per tal de «no perecer». La situació es va mantindre fins al començament del segle xIx; el metge Antoni Cibat, en la seua Memòria sobre l'avanç de les febres tercianes més enllà dels seus llocs naturals, escrivia:

Las tercianas, esta enfermedad que antes acantonada en los parages húmedos y pantanosos, acometía benignamente tan solo á los habitantes de estos mismos lugares, no solo ha saltado sus antiguas barreras pasando de los valles á las sierras, y de unas provincias á otras, sino que malignándose han llegado á ser epidémicas, y á dexar yermos los pueblos por donde pasan. ${ }^{79}$

Les Memorias de la Real Academia Médico-Práctica de Barcelona arrepleguen els efectes de les febres pútrides que a partir de febrer de 1786 van afectar la vila d'Ulldecona, ressenyats pel metge Francesc Espasa. ${ }^{80}$ Es fan ressò igualment de l'àmplia i detallada Descripció de l'epidèmia de febres que va patir Roses, des de l'estiu de 1789 fins a la primavera de 1790 , escrita pel seu metge titular, Francesc Suñer. ${ }^{81}$ La Gazeta de Madrid, per la seua banda, informava a la fi de novembre de 1789 dels efectes causats per la combinació de febres tercianes i tifus a Artés, petita localitat del corregiment de Manresa, combatuts amb eficàcia per

79. Antonio Cibat, Memoria sobre el problema ¿Por qué motivos ó causas las tercianas se han hecho tan comunes y graves en nuestra España ¿Con qué medios podrian precaverse y destruirse? Escrita por don [...], Doctor en Medicina y Cirugía, Catedrático del Real Colegio de Cirugía Médica de Barcelona [...], Imprenta Real, Madrid, I8o6, pp. I-2.

8o. «Noticia de una epidemia observada en la villa de Ulldecona, Principado de Cataluńa, por el doctor don Francisco Espada, socio íntimo, Lleida en 3 de diciembre de 1787", dins Memorias de la Academia Médico-Práctica de Medicina de la ciudad de Barcelona, Imprenta Real, Madrid, I798, I, pp. 378-383.

8I. "Descripción de la epidemia que se padeció en la villa de Rosas, Principado de Cataluña, desde el mes de agosto de 1789 hasta el mes de mayo de I790, y su método curativo, por el doctor don Francisco Suñer, corresponsal, médico de la misma villa, leída en las Juntas de 2I y 28 de febrero de I79I», dins Memorias de la Academia MédicoPráctica de Medicina de la ciudad de Barcelona, Imprenta Real, Madrid, I798, I, pp. 384-407. 
Francesc Llorens, metge desplaçat fins a la vila per ordre del capità general de Catalunya. ${ }^{82}$

Sobre l'Empordà, comarca catalana especialment sensible a l'escomesa de les febres per les seues característiques topogràfiques, el doctor Francesc Pons, metge de l'hospital i de la vila de Figueres, va publicar en I790 una àmplia Memòria pràctica sobre les febres pútrides suportades per la vila, entre d'altres, els anys I784 i I785, i que va merèixer l'aval de l'Acadèmia de Medicina de París i el de l'Acadèmia Medicopràctica de Barcelona. ${ }^{83}$ Amb un enfocament eminentment pràctic, Pons desgranava $\mathrm{amb}$ precisió totes les variants amb què es presentaven les febres en l'ampli territori empordanès, les causes que les provocaven i els remeis que s'havien d'aplicar per a aconseguir, si no una curació absoluta, sí, almenys, una millora de les condicions de vida dels malalts.

En aquest context resulta de gran interès el memorial que Juan Vives i Puig, advocat i membre de l'Audiència de Catalunya, va remetre al comte de Floridablanca al començament de maig de 1787 , en el qual, entre altres coses, advertia de «las varias y innombrables epidémicas fiebres y enfermedades» que patien els veïns «de los lugares del hondo del Ampurdán». ${ }^{84}$ Oriünd de la petita població de Peratallada — pròxima a Pals, en el Baix Empordà- i, en conseqüència, molt sensibilitzat amb els riscos sanitaris del territori, Vives — com Cavanilles a Valènciaculpava l'exagerada extensió dels arrossars i l'abundància de zones entollades de la constant presència de febres tercianes i de la sagnia demo-

82. Gazeta de Madrid, núm. 78 (29-9-1789), p. 626.

83. Francisco Pons, Memoria práctica sobre las calenturas pútridas del Ampurdán por el Maestro en Artes y Doctor en Medicina [...], de la Real Sociedad de Medicina de París y Médico del Hospital y villa de Figueras, Viuda Eulalia Piferrer, Barcelona, I790.

84. Arxiu Històric Nacional (AHN), Consejos, lligall 37168, núm. 6, D. Juan Vives y Puig, vecino de la ciudad de Barcelona y abogado de la Real Audiencia de aquel Principado, sobre reparar la despoblación, falta de comercio y escasez de granos que se experimenta en casi todos los lugares del Ampurdán. Armando Alberola Romá i Jesús Pradells Nadal, «Sequía, inundaciones, fiebres y plagas en tierras aragonesas y catalanas (1780-1790)", a D. Bernabé i A. Alberola, eds., Magistro et amico. Diez estudios en Homenaje al profesor Enrique Giménez López, Publicacions de la Universitat d'Alacant, Alacant, 2012, pp. 65-93. 
gràfica que provocaven tots els anys, per la qual cosa proposava que es prohibira el seu conreu.

La insalubritat del medi havia provocat el trasllat dels propietaris agraris més poderosos i les seues famílies cap a llocs més saludables, i tan sols tornaven a les seues possessions per a passar curtes estades, ja fora a l'hivern o abans de sembrar l'arròs. En conseqüència i tal com Vives sentenciava, tan sols quedaven en els perillosos enclavaments els qui no tenien altres horitzons, és a dir, «los menesterosos, cuatro aparceros y algunos emigrantes montañeses». Al problema sanitari i humà, per tant, se n'hi afegia un altre de natura econòmica, i no menys greu. El predomini de l'arròs, propiciat pel seu major rendiment i la seva rendibilitat, havia ocasionat un sensible descens, si no desaparició, del cultiu d'altres productes i una perillosa baixada dels intercanvis comercials. Així, malaltia, pobresa i despoblació es conjugaven i oferien un sòrdid panorama per a la millora del qual Juan Vives plantejava en la seua llarga memòria un decidit sanejament del medi, la dràstica prohibició del conreu arrosser, juntament amb una aposta seriosa per recuperar els cereals, incrementar la producció d'hortalisses i fruites i, fins i tot, assajar la plantació de moreres per a fomentar la cria del cuc de seda.

En el tram final del segle XviII es van unir l'extremisme climàtic propi de l'oscillació Maldà, les males collites, la fam i la malaltia, que assetjaren amb ferotgia una societat per si mateixa molt afeblida. El paludisme va ocasionar grans i greus problemes, atesos el seu caràcter endèmic i l'estreta vinculació existent entre excés d'aigua i febres. Els camperols esperaven, amb fatalisme resignat, la seua metòdica irrupció estival, la seua alta morbiditat, la seua moderada mortalitat i els seus efectes invalidants per a desenvolupar les tasques agrícoles, pel grau de prostració al qual condemnava als qui emmalaltien. De ben segur, els treballs que s'estan concloent a hores d'ara sobre aquesta interessantíssima qüestió de la presència de les febres, tant el paludisme com la febre groga, en el Mediterrani occidental entre els anys I75O-I850, ${ }^{85} \mathrm{Con}$ -

85. Em referisc a la tesi doctoral de Kevin Pometti que, sota el títol «Inestabilidad ambiental y salud pública en una ciudad mediterránea del Antiguo Régimen. 
tribuiran a ampliar el coneixement dels efectes d'aquesta malaltia, tan vinculada al medi i amb terribles efectes socials i econòmics.

\section{Consideració final}

Al llarg d'aquestes pàgines he repassat alguns dels paisatges que integraven aqueix Mediterrani global que, de manera pionera, va analitzar Fernand Braudel. El gran historiador francès ja va advertir de l'existència d'un conjunt de mars i de paisatges heterogenis, encara que va prestar una atenció especial als relacionats més estretament amb els aspectes fisicogeograficoclimàtics, que, de manera indefectible, solen conduir cap als sectors agrícola i comercial. Paisatges que tant podien ser terrestres com marítims.

Els efectes de la petita edat del gel van condicionar el desenvolupament de la vida quotidiana i de les activitats polítiques i econòmiques. El fred i la calor, la sequera i l'excés d'aigua, els vaivens meteorològics segons l'estació atmosferrica, entre altres elements, van influir poderosament en l'evolució normal de les societats mediterrànies durant l'edat moderna. Per açò he prestat una atenció especial a la singularitat que oferia el mar durant l'hivern i l'estiu, perquè, al cap i a la fi, era en aquestes dues llargues estacions quan la navegació podia ser plena i rendible o perillosa i arriscada.

També he volgut destacar el problema de l'aigua, existent en l'àmbit mediterrani des de sempre, $o$ bé per la seua absència perllongada, $o$ bé pel seu excés puntual i desmesurat. Sequera i inundació configuren un paisatge recognoscible $i$ tant si es donara l'una com si es donara l'altra, el desastre estava servit. Igual com succeeix en els nostres dies. Emperò es plantejaren solucions preventives de caràcter tècnic $\mathrm{i}$, una vegada consumada la catàstrofe, entraren en acció remeis de caràcter espiritual considerats eficaços i, per açò, sempre prests a actuar des de

Barcelona entre el paludismo y la fiebre amarilla (I780-I82I)», va ser defensada a la Universitat d'Aix-Marseille el 4 de desembre de 2019. 
la religiositat popular, encara que la realitat desmentira les seues hipotètiques virtuts.

L'explotació salinera, aqueix eufemístic però enormement rendible "cultiu del mar», va configurar un altre paisatge típicament mediterrani en el qual les feines recol-lectores de la sal en terra ferma - encara que entollada - es conjugaven amb els molt remuneradors viatges marítims; quasi conformaven, podríem dir, dos paisatges en un. I no podem oblidar aqueix altre negoci, no menys beneficiós, que va sorgir del fred i, per tant, estretament relacionat amb la petita edat del gel, com va ser la recollida, conservació i comercialització de la neu, que explicava — i compte! — amb el seu particular paisatge muntanyès farcit de pous i neveres a molt diferents altituds, però a vegades a tan pocs metres sobre el nivell del mar que, des de la nostra perspectiva actual, dominada per l'escalfament climàtic, se'ns apareixen com testimonis muts i inversemblants d'un passat molt més fred.

Finalment, la por, el patiment i la malaltia conformen "paisatges» ben definits que els nostres avantpassats mediterranis van entendre com a propis d'un medi que, geològicament i sanitàriament, podia comportar-se amb agressivitat i ocasionar danys importants. De la mateixa manera, les febres tercianes, malaltia estretament vinculada a un territori ple d'àrees entollades i deprimides, van configurar un altre paisatge en el qual, com en pocs més, es van barrejar vida, malaltia i mort, tot donant lloc a un patiment continu assumit amb un fatalisme no menys mediterrani per tots els qui emmalaltien. 